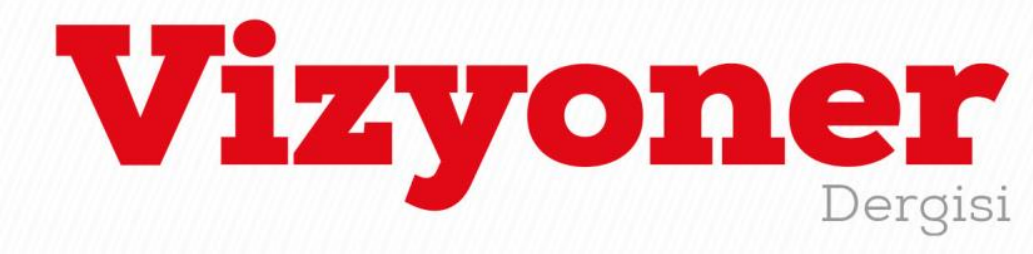

Süleyman Demirel Üniversitesi Vizyoner Dergisi, Yıl: 2021, Cilt: 12, Sayı: 31, 752-765.

Süleyman Demirel University Visionary Journal, Year: 2021, Volume: 12, No: 31, 752-765.

\title{
BURDUR GENÇLİK VE SPOR İL MÜDÜRLÜĞÜ ÇALIŞANLARININ LİDER OLMA ENDISSELERINIIN INCELENMESI*
}

\section{INVESTIGATION OF THE WORRIES ABOUT LEADERSHIP OF THE PERSONNELS AT PROVINCIAL DIRECTORATE OF YOUTH AND SPORT IN BURDUR}

\author{
Dr. Öğr. Üyesi Hasret ÖZTÜRK ${ }^{1}$
}

ÖZ

\begin{abstract}
Araştırmanın amacı Burdur Gençlik ve Spor İl Müdürlüğünde çalışan personelin lider olma endişe düzeylerini tespit etmektir. $\mathrm{Bu}$ amaçla betimsel tarama modeli kullanılmıştır. Araştırmaya Burdur Gençlik ve Spor İl Müdürlügünde çalışan 38 memur ve 207 işçi olmak üzere 245 kişi katılmıştır. Araştırmanın verileri araştırmacı tarafından İngilizce'den Türkçe'ye uyarlanan lider olma endişesi ölçeği kullanılarak toplanmıştır. Araştırmanın analizleri Burdur Gençlik ve Spor İl Müdürlüğünde çalışan personelin lider olma endişesi algıları istihdam türü, cinsiyet, medeni durum, mesleki kıdem, eğitim düzeyi, geçmiş yöneticilik deneyimi, yönetici olma istekleri değişkenlerine göre yapılmıştır. Buna göre çalışanların lider olma endişelerinin istihdam türü, cinsiyet, eğitim düzeyi, geçmiş yöneticilik deneyimi, yönetici olma istekleri değişkenlerine göre farklılaştığ sonucuna ulaşılmıştır Araştırmada elde edilen veriler sonucunda çalışanların lider olma endişelerini azaltmak için liderliğe hazırlayıcı temel eğitimler ile kriz ve stres yönetimi eğitimleri önerilmiştir.
\end{abstract}

Anahtar Kelimeler: Kamu Sektörü, Lider, Lider Olma Endişesi.

JEL Sınıflandırma Kodları: J18, M12.

\section{ABSTRACT}

The aim of the study is to find out the perceptions on the worries about leadership of the personnel who work at Burdur Provincial Directorate of Youth and Sport. For that purpose, descriptive survey model is used. 245 personnel working at the Burdur Provincial Directorate of Youth and Sport, consisting of 38 officers and 207 workers, attend the research. The data of the research are collected by the researcher by using the worries about leadership scale which is adapted to Turkish from its English version. The analysis of the study is carried out in accordance with the variables of the personnel who work at Burdur Provincial Directorate of Youth and Sport, such as perceptions on worries about leadership, type of employment, gender, marital status, professional seniority, educational level, past leadership experiences, the will to become a leader. In conclusion, it is found out that the worries about leadership of the personnel differ on the basis of variables such as type of employment, gender, educational level, past leadership experiences, the will to become a leader. Considering the data obtained during the research, basic trainings preparatory for leadership and trainings on crisis and stress management is offered to reduce the personnel's worries about leadership.

Keywords: Public Sector, Leader, Worries about Leadership.

JEL Classification Codes: J18, M12.

* Bu çalışma için Burdur Mehmet Akif Ersoy Üniversitesi Etik Kurulundan 2021/01 toplantı ve 2021/25 sayılı ve 06.01.2021 tarihli etik kurul onayı alınmışıtır.

1 (D) Burdur Mehmet Akif Ersoy Üniversitesi, Sosyal Bilimler Meslek Yüksekokulu, Büro Hizmetleri ve Sekreterlik Bölümü, hozturk@mehmetakif.edu.tr

Makale Geliş Tarihi / Received : : 02.02 .2021

Makale Kabul Tarihi / Accepted $\quad: 18.06 .2021$

DOI: 10.21076/vizyoner.873381 


\section{EXTENDED SUMMARY}

\section{Purpose and Scope:}

The aim of the research is to determine the level of worries about leadership of the personnel who work at Burdur Provincial Directorate of Youth and Sport. Accordingly, the scope of the research consists of the officers who work at Burdur Provincial Directorate of Youth and Sport.

\section{Design/methodology/approach:}

Descriptive survey model was used as the research model. The descriptive survey model is used in research to determine the perspectives and perceptions of the sample group over the subject being researched. In this direction, descriptive survey design was used to determine the levels of worries about leadership of the personnel who work at Burdur Provincial Directorate of Youth and Sport (Dönmez and Uslu; 2013: 4). 245 personnel working at the Burdur Provincial Directorate of Youth and Sport, consisting of 38 officers and 207 workers, attended the research. Accordingly, the data obtained from 38 officers and 207 workers were analyzed.

\section{Findings:}

It was found out that the worries about leadership of the personnel were differed on the basis of variables such as type of employment, gender, educational level, past leadership experiences, the will to become a leader, but not differed on the basis of variables such as marital status and professional seniority.

\section{Conclusion and Discussion:}

As a result of the findings obtained, it was found out that the personnel of the Burdur Provincial Directorate of Youth and Sport in Burdur have a high level of worries about leadership. Besides, this might have been due to the personal characteristics of the employees such as lack of knowledge and self-reliance, it might also be due to the restrictive and detailed legislation in organizational structure restricting the range of action, and the reaction by the personnel to the requests for change in the corporate structure that the leadership role would bring (Anderson, Brien, McNamara, O'Hara and McIsaac, 2011; Chan and Drasgow, 2001; Şahin and Gül, 2011: 246-247). The worries of the officers about leadership are lower in the sub-scale "failure" compared to workers. This situation may be due to the fact that the officers have a wider field of duty than workers on the ground they are subject to State Personnel Law numbered 657, and they have more control over the organizational structure and work processes. On the other hand, the fact that there is no difference in the sub-scales of the "worries about the balance of work and private life" and "the worries of hurting himself and his colleagues" may be due to the regulation of working conditions with predictable legislation. In other words, the fact that the officers are subject to the State Personnel Law numbered 657 and the Labor Law numbered 4857 can shape their working conditions, the time they devote to themselves and their private lives, and their sensitivity towards their colleagues. It is observed that women have higher levels of worries in the sub-scale of fear of hurting themselves and their colleagues compared to men. This may be due to the roles society gives to women. Women have more sensitive, compassionate, protective and mother roles than men. For this reason, it is likely that they will show more sensitivity about not hurting themselves and those around them (Günay and Bener, 2011: 167; Pekel, 2019: 31-33). It is observed that gender roles do not have an effect in the sub-scale of worries of failure. In the same direction, Çekiç (2016: 87) concluded that personnel's worries about leadership are not affected by the gender factor. The fact that there is no difference in terms of gender in worries about the balance of work and private life can be explained by the fact that the working hours and vacation times of female and male personnel are regulated by the State Personnel Law numbered 657 and the Labor Law numbered 4857 , so that the workers have the opportunity to allocate enough time to their business and family lives. It is observed that personnel, who graduated high school or have a lower educational level, have high levels of worries about failure and those who graduated associate's degree and above education level are found to have low level. In the same direction, Elmuti, Minnis and Abebe (2005: 1026) stated that the skills of the personnel improved, their self-reliance increased and their fear of failure decreased in proportion to educational level. In other words, it was stated that as the education level of public personnel working in conditions where corporate pressure elements are felt intensely, such as legislation, their awareness of this institutional environment may increase and they can build up knowledge about how to respond to the demands of the institutional environment. The fact that there is no significant difference between the worries about the balance of work and private life and the worry of hurting themselves and their colleagues according to the educational level may be due to the fact that the relevant legislation, which regulates working conditions, give the same rights and responsibilities to all personnel. The personnel, who did not have previous management experience, had high levels of anxiety in the sub-scales of worries of failure and the worry of hurting themselves and their colleagues. Similarly, according to Araç Ilgar (2019: 70-75), public personnel, who had more managerial experience, have enough confidence in themselves because they have experienced work processes before, and this situation reduces their levels of worries. The fact that there is no difference in the sub-scale of the worries of not being able to balance work and private life among personnel may be due to the fact that the relevant legislation, which regulates work and private life, provides equal rights to all personnel. 


\section{GİRIŞ̧}

Toplumsal yaşamın her alanında görülen liderler son zamanlarda iş yaşamında da önem kazanmaya başlamıştır. Özellikle örgütlerin amaçlarına ulaşmasında etkinlik ve verimliliğin sağlanmasında liderler önemli rollere sahiptir (Tunçer, 2011: 76). Genelde çalışanlar lider olmanın sağlayacağı avantajlardan faydalanmak için bu rolü üstlenmeyi istemektedirler. Fakat lider olmak olası başarısızlıkları, yoğun iş temposunu, emrinde çalışanlarla yaşanabilecek sorunları da beraberinde getirmektedir. Bu durum bazı çalışanları lider olma konusunda bir takım kaygılara ve kararsızlıklara sevk etmektedir. Bununla birlikte çalışanların lider olma endişelerini lider olacağı örgüt yapısı da önemli ölçüde etkilemektedir (Anderson, Brien, McNamara, O’Hara ve McIsaac, 2011; Chan ve Drasgow, 2001).

Özelikle kamu örgütlerinin uygulamak zorunda oldukları katı mevzuat, hiyeraşik örgüt yapısı, rutinleşmiş faaliyetler ve iş süreçleri ile değişime karşı olan çalışanlar kamu örgütlerinde lider olma endişelerini daha da artırabilmektedir. Fakat kamu örgütlerinin hedeflerine ulaşması için değişimi gerçekleştirecek, çalışanlara yön verecek bir lidere her zaman ihtiyacı bulunmaktadır (Şahin, Taşpınar, Eryeşil ve Örselli, 2016: 75-76). Bu nedenle kamu çalışanların lider olma endişelerini tespit edilmesi ve endişelerini azaltacak çözüm önerileri sunulması önem arz etmektedir. Bu kapsamda bu çalışmanın amacı Burdur Gençlik ve Spor İl Müdürlüğü çalışanlarının lider olma endişelerinin belirlenmesidir.

\section{LIDER KAVRAMININ TANIMI VE ÖNEMI}

Lider kavramının tanımı kültürlere ve kişilere göre farklı1ık gösterebilmektedir (Baloğlu, 2011: 128). Ama genel olarak lideri tanımlayacak olursak lider, içinde bulunduğu ortam ve durumları değiştiren ve bu değişim doğrultusunda kişileri harekete geçiren kişi olarak tanımlanmaktadır (Çelik, 1997: 470-471). İş yaşamında lider ise örgütlerin geleceğe yönelik hedeflerine ulaşması için çalışanlarına yeni ilke ve prensipler benimseten, bu ilke ile prensipler doğrultusunda çalışanları motive eden ve değişimi başlatan ve yöneten kişi olarak ifade edilebilir. $\mathrm{Bu}$ doğrultuda lider çevreden etkilenen değil, çevresini etkileyen, değişimi gerçekleştiren (Eraslan, 2004: 4) ve yeni bir örgüt kültürü oluşturan kişi olarak karşımıza çıkmaktadır (Tunçer, 2011: 63). Lider, örgütün amaçlarına ulaşmasında ve başarısında önemli rol oynamaktadır. Çünkü örgütsel başarıda vazgeçilmez kaynaklardan biri olan insan kaynağı tanımak, harekete geçirmek, etkinliğini ve verimliğini sağlamak gibi görevler ancak liderler tarafindan yerine getirebilmektedir (Yeşil, 2016: 175-176).

İş yaşamında liderin bir takım özelliklere sahip olması gerekmektedir. Bunlar, tüm çalışanlar tarafindan benimsenen vizyon ortaya koymak (Tahaoğlu ve Gedikoğlu, 2009: 280), yaratıcı fikir ve düşünceler sunmak, etkili ve doğru iletişim tekniklerini kullanarak motivasyon yaratmak, zorluklar, stres ve eleştiriler karşısında duygusal açıdan dayanıklı olmak, özgüven ve cesarete sahip olmak, gerektiğinde risk alabilmek ve değişimin öncüsü olmak şeklinde sıralanmaktadır (Eraslan, 2004: 13-29). Görüldüğü üzere lider olmak birtakım ağır sorumlulukları, yükümlülükleri ve çatışmaları da beraberinde getirmesi muhtemeldir.

\section{LIDER OLMA ENDISSESI}

Lider olmak her şeyden önce bireysel bir tercih meselesi olarak karşımıza çıkmaktadır. Genellikle de arzu edilen ayrıcalıklı bir konum olarak tasvir edilmektedir. Fakat ağır sorumluluklar ve özel yaşamda verilen tavizler liderliği toplumun büyük çoğunluğu tarafından arzu edilmeyen, hatta kaçınılan bir duruma dönüştürebilmektedir. $\mathrm{Bu}$ özellikleri nedeniyle lider rolü ilgili kararların genellikle uzun ve çetrefilli bir karar süreci sonunda verilmesine yol açabilmektedir. Başka bir ifadeyle, lider olmak insanların üstlenmek için can attığı ve mutlulukla kucakladığı bir rol olmayabilir. Hatta başarılı ve yetenekli çalışanlar çoğunlukla öne çıkmayı, yöneticilik ve lider rollerini üstlenmeyi reddetmektedir. Bu durum, iş yaşamında liderliğin çoğunlukla eksikliği hissedilen bir göreve dönüşmesine yol açmaktadır (Epitropaki, 2018). Aycan ve Shelia (2019) örgütlerde liderliğin teşvik edildiği halde çalışanların neden liderlik rolünden kaçındıklarını betimlemek için "Lider Olma Endişesi" kavramını geliştirmiştir. Lider olma endişesi hem yüksek lider olma potansiyeli olduğu halde ileri çıkmayan insanların durumunu hem de kadınlar gibi üst kademelerde yeterince temsil edilmeyen grupların durumunu betimlemede kolaylık sağlayabilmektedir. Lider olmak genellikle örgütün hiyerarşisi içinde formel bir rol üstlenmeyi gerektirmektedir. Fakat lider olma endişesi insanların lider olma veya olmama yönündeki seçimlerinin duygularının etkisi altında şekillendiği varsayımına dayanmaktadır (Aycan ve Shelia, 2019). 
Lider olma endişesi üç boyuttan oluşmaktadır. Bunlar başarısız olma endişesi, iş-yaşam dengesizliğine ilişkin endişe ile kendine ve diğer insanlara zarar verme endişesidir. Liderler de zaman zaman başarısızlıklar yaşamakta ve başarısızlıkların sonuçlarıyla mücadele etmektedirler. Başarısızlık yalnızca takipçilerin hoşnutsuz olmalarına yol açmamaktadır. Aynı zamanda liderlerin kendi yetkinlikleri sorgulamalarına neden olmaktadır. Bu nedenle, günlük yaşamında kaygıdan uzak olan insanlar dahi lider olmaları söz konusu olduğunda endişeye kapilabilmektedir (Giessner ve Van Knippenberg, 2008).

Benzer şekilde iş-yaşam dengesizliği özerklik ihtiyacının karşılanmasına tehdit oluşturmaktadır. Lider rolü iş yaşamındaki özerklik düzeyini artırırken toplumsal yaşamdaki özerkliği kısıtlayabilir. Özellikle ailelerine ve özel yaşamlarına yeterince vakit ayıramamaları liderlerin en çok şikâyet ettikleri konular arasında yer almaktadır (Brue, 2018). Son olarak, liderlerin verdikleri kararların kendine ve diğer insanlara zarar verme olasılığı insanlar için güçlü bir endişe kaynağı olabilmektedir. Zira bu durum ilişki kurma ihtiyacının tatmin edilmesine yönelik bir tehdittir. Özellikle istismarcı ve yıkıcı lider davranışlarına ilişkin farkındalığın artması, insanların lider rolünün olumsuz sonuçları hakkındaki endişelerini pekiştirmektedir (Aycan ve Shelia, 2019).

Benzer duruma kamu örgütlerinde rastlanmaktadır. Hatta kamu yönetimi alanında liderlik konusunda eğitim görenlerde dahi liderlik olmak söz konusu olduğunda isteksizlik gözlenebilmektedir. Lider imajıyla ilgili sorunlar, iş yükü, önyargı, kişilik, yetersizlik hissi, kurumsal çevrenin kısıtlayıcılığı ve çevresel belirsizlik gibi etkenler liderliği kamu çalışanları için endişe verici bir role dönüştürebilmektedir (Anderson, Brien, McNamara, O’Hara ve McIsaac, 2011; Chan ve Drasgow, 2001). Ayrıca kamu sektörlerine özgü durumlar kişinin lider olma isteğine ket vurmakta ve liderlik rolleri ve uygulamaları ile tezatlık oluşturmaktadır. Bunlar, merkezden yönetim tarzının benimsenmesi, yetki devrinin kısıtlı olması, günlük işlerin dışına çıkmaktan çekingen davranan üst yönetimin ve çalışanların olması, değişiklere karşı çıkan yapının bulunması, uzun dönemli planlamaların olmaması, yönetici ve çalışanlar arasında etkin iletişim ağının sağlanamaması ve nepotizm şeklinde sıralanmaktadır (Şahin ve Gül, 2011: 246-247).

Yukarıdaki açıklamalar ışığında genel olarak Burdur Gençlik ve Spor İl Müdürlüğü çalışanlarının lider olma endişelerinin yüksek düzeyde çıkması beklenebilir. Ayrıca memurların lider olma endişelerinin işçilere göre daha düşük düzeyde çıkması beklenmektedir. Çünkü memurların 567 sayılı Devlet Memurları Kanuna tabi olmaları nedeniyle geniş görev tanımlarına sahiptirler. Bu nedenle kurumun iş ve işleyiş süreçlerine hâkimdirler. Bununla birlikte yükselme ihtimallerinin işçilere göre daha yüksek olması lider olmaya onları daha hazırlıklı hale getirebilmektedir. Bu doğrultuda alanyazında Rigby, (2014), Spillane, Hallett ve Diamond, (2003) kamu kurumlarında çalışanların lider olma endişelerini etkileyen önemli faktörün iş yaşamını düzenleyen kanunlar olduğunu ifade etmişlerdir.

Kadınların lider olma endişelerinin erkeklere göre daha yükssek düzeyde olması beklenebilir. Çünkü iş yaşamında kadınların liderlik rolü ile bağdaşmadıklarına yönelik örtük bir ön yargı bulunmaktadır. Ayrıca kadınların kendilerinden kaynaklanan ailelerine vakit ayırama endişesi gibi etkenler de lider olma endişelerini olumsuz yönde etkileyebilmektedir (Akbaş ve Korkmaz, 2017: 74-75; Mırahı ve Aracı, 2010: 150).

Bekâr çalışanların evlilere göre daha az lider olma endişelerine sahip olmaları beklenebilir. Çünkü bekâr çalışanlar evlilere nazaran daha az rol ve sorumluluklara sahiptirler. Bu nedenle lider olma konusunda daha çok istekli olabilmektedirler (Binen, 2013: 75).

Mesleki kıdemi fazla olan çalışanların lider olma endişelerinin daha az düzeyde çıkması beklenebilir. Çünkü mesleki kıdem artıkça çalışanların deneyim ve tecrübeleri artmaktadır. Bu nedenle mesleki kıdemi fazla olan çalışanların liderlik rolü üstlenme konusunda görece daha istekli olduklarını ileri sürmek mümkündür (Hoşgör, Hoşgör ve Memiş, 2016: 354).

Eğitim durumu yüksek çalışanların lider olma endişelerinin daha yüksek düzeyde çıkması beklenmektedir. Çünkü eğitim düzeyi yüksek çalışanlar çalıştıkları kurumun iş ve işleyişinde ne tür sorunların olduğunun daha çok farkında olduklarından endișe düzeyleri de yüksek olabilmektedir (Soysal ve Baynal, 2016: 261).

Daha önce yöneticilik yapmış çalışanların lider olma endişelerin daha düşük düzeyde çıkması beklenmektedir. Çünkü daha önce yöneticilik yapan çalışanlar geçmiş deneyimlerinden dolayı örgütsel yapıyı daha iyi tanımaktadırlar. Aynı zamanda kendilerine olan özgüvenleri daha fazladır. Aynı şekilde yöneticilik yapma ve kariyer planlaması düşüncesi olan çalışanların lider olma endişe düzeylerinin düşük düzeyde çıkması beklenmektedir. Çünkü liderlik rolü birlikte planladıkları arzu ettikleri mevki ve kariyer hedeflerine ulaşma imkânı 
bulabileceklerini düşünmektedirler. Bu durum endişeden çok istekliliği öne çıkarabilmektedir (Araç Ilgar, 2019: 74-75; Günay ve Özbilen, 2018: 1341).

Yukarıdaki açıklamalar doğrultusunda, bu çalışmanın temel amacı Burdur Gençlik ve Spor İl Müdürlüğü çalışlarının lider olma endişesi düzeylerinin belirlenmesidir. Bu temel amaç doğrultusunda aşağıdaki sorulara cevap aranmaya çalışılmıştır.

- Burdur Gençlik ve Spor İl Müdürlüğü çalışanlarının lider olma endişeleri ne düzeydedir?

- Burdur Gençlik ve Spor İl Müdürlüğ̈̈ çalışanlarının lider olma endişesi düzeyleri istihdam türü, cinsiyet, medeni durum, meslekteki kıdem ve eğitim durumu, geçmiş yöneticilik deneyimi, herhangi bir kurumda yönetici olma veya daha üstü görevlerde kariyer yapma düşüncelerine göre farkl1l1k göstermekte midir?

\section{YÖNTEM}

Bu bölümde araştırma deseni, evren ve örneklem, veri toplama aracı ve veri analizine ilişkin başlıklara yer verilmiştir. Ayrıca bu çalışmanın etik kurallara uygunluğu, Burdur Mehmet Akif Ersoy Üniversitesi'nin 06.01.2021 tarih ve 2021/01 toplantı ve 2021/25 karar numaralı etik kurul raporu ile onaylanmıştır.

\subsection{Araştırma Deseni}

Araştırma deseni olarak betimsel tarama deseni kullanılmıştır. Betimsel tarama deseni araştırmalarda örneklem grubunun araştırılan konuyla ilgili bakış açıları ve algılarını belirlemek amacıyla kullanılmaktadır. Bu doğrultuda Burdur Gençlik ve Spor İl Müdürlüğü çalışanlarının lider olma endişe düzeylerini belirlemek amacıyla betimsel tarama deseni kullanılmıştır (Dönmez ve Uslu, 2013: 4)

\subsection{Araştırmanın Evren ve Örneklemi}

Araştırmaya Burdur Gençlik ve Spor İl Müdürlüğünde çalışan 38 memur ve 207 işçi olmak üzere 245 kişi katılmıştır. Araştırmada tabakalı örnekleme yöntemi kullanılmışıır. Tabakalı örnekleme yönteminin kullanılması nedeni araştırma yapılan kurumda iki ayrı istihdam türü bulunmasından kaynaklanmaktadır. Veriler ilgili kurumdan izin alınarak toplanmıştır. Yapılan ilk analizler neticesinde uç değer bulunmadığı tespit edilmiş bu nedenle herhangi bir katılımcıdan elde edilen veri çıkarılmamıştır.

\subsection{Veri Toplama Aracı}

Aycan ve Shelia, (2019) tarafından geliştirilen ölçek, üç dil uzmanı tarafindan İngilizce'den Türkçe'ye çevrilmiştir. Yapılan çeviriler araştırmacı tarafindan incelenerek ölçeğin Türkçe taslağ Oluşturulan taslak Türk dili ve kamu yönetimi alanında uzman 7 akademisyene gönderilerek görüşleri alınmıştır. Son şekli verilen ölçek yeniden üç dil uzmanı tarafından İngilizce'ye çevrilerek orjinali ile aralarında tutarlılık olup olmadığı incelenmiştir. Bu çalışmalar neticesinde ölçeğe son hali verilerek uygulama safhasına geçilmiştir. Ölçeğin geçerlik güvenirlik analizi sonucunda açıklanan toplam varyans oranı $\% 59.82$ olarak bulunmuştur. Maddelerin faktör yük değerleri ile her bir faktörün açıkladığı varyans ve Cronbach Alfa değerleri Tablo 1'de sunulmuştur.

Tablo 1. Maddelerin Faktör Yük Değerleri ile Her Bir Faktörün Açıkladığı Varyans ve Cronbach Alfa Değerleri

\begin{tabular}{cccc}
\hline Madde Sura No & Başarısız Olma Endişesi & $\begin{array}{c}\text { İş ve Özel Yaşam Dengesi } \\
\text { H. Endişeler }\end{array}$ & $\begin{array}{c}\text { Kendine ve Çevresine } \\
\text { Zarar Verme Endişesi }\end{array}$ \\
\hline 1 & .59 & \\
13 & .67 & \\
15 & .81 & \\
9 & .81 & .62 \\
5 & .59 & .77 \\
2 & & .68 \\
14 & & .62 \\
16 & &
\end{tabular}




\begin{tabular}{|c|c|c|c|}
\hline Madde Sura No & Başarısız Olma Endişesi & $\begin{array}{c}\text { İş ve Özel Yaşam Dengesi } \\
\text { H. Endişeler }\end{array}$ & $\begin{array}{l}\text { Kendine ve Çevresine } \\
\text { Zarar Verme Endișesi }\end{array}$ \\
\hline 4 & & .82 & \\
\hline 8 & & .75 & \\
\hline 11 & & & .59 \\
\hline 10 & & & .60 \\
\hline 12 & & & .53 \\
\hline 7 & & & .50 \\
\hline 3 & & & .34 \\
\hline Açıklanan Varyans & $\% 31.1$ & $\% 18.4$ & $\% 10.34$ \\
\hline Cronbach Alfa & .74 & .84 & .81 \\
\hline
\end{tabular}

Tablo 1'de görüldüğü gibi ölçek maddelerinin faktör yük değerleri .34 ile .82 arasında değişmektedir. Cronbach Alfa değerleri.74 ile .84 arasındadır.

\subsection{Verilerin Analizi}

Verilerin analizi için SPSS 22 programı kullanılmıştır. Verilerin normal dağılıp dağılmadığını belirlemek için grafik ve betimsel yöntemler kullanılmıştır. Grafik yöntemler arasında kutu-bıyık (boxplot) grafikleri ve Q-Q grafikleri kullanılmıştır. Kutu bıyık grafikleri incelendiğinde verilerin ortancalar etrafında bakışı yayıldığı görülmüştür. Q-Q grafikleri ise, gerçekleşen değerler ile beklenen değerler örtüşmesi sonucunda ortaya 45 derecelik açı yapan bir doğru ortaya çıktığını göstermektedir Betimsel yöntemle verilerin normallik varsayımını karşılanıp karşılanmadığını belirlemek için çarpıklık ve basıklık katsayıları incelenmiştir. Çarpıklık ve basıklık katsayıları -1.5 ile +1.5 arasında bir değer olması önerilmektedir (Garson, 2012; 18-25). Bu çalışmada bu değerler -1.07 ile +0.31 arasında değişmektedir.

Verilerin analizinde ortalama, standart sapma gibi betimsel istatistikler kullanılmıştır. İstihdam türü, cinsiyet, medeni durum, eğitim durumu, geçmişteki yöneticilik deneyimi, yönetici olma isteklerine göre katılımcıların lider olma endişelerinden farklılık gösterip göstermediği t-testi ile sınanmıştır. 21 yıl ve üzeri kıdeme sahip 14 katılımcı olduğu için mesleki kıdeme göre katılımcıların lider olma endişelerinin farklılaşıp farklılaşmadığı parametrik olmayan testler arasında yer alan Kruskal Wallis-H Testi ile sınanmıştır. Anlamlılık testleri 0.05 düzeyinde yapılmıştır.

\section{BULGULAR}

Aşağıda tablo 2'de başarısız olma endişesi alt boyutuna ilişkin aritmetik ortalama, standart sapma ve göreli önem sira değerleri sunulmuştur.

Tablo 2. Başarısız Olma Endişesi Alt Boyutuna İlişsin Aritmetik Ortalama, Standart Sapma ve Göreli Önem Sıra Değerleri

\begin{tabular}{|c|c|c|c|c|c|}
\hline Md. No. & İfadeler & Görev & $\bar{X}$ & ss & Önem Sırası \\
\hline \multirow{3}{*}{1} & \multirow{3}{*}{ Yaptığım hataların daha fazla göze batması } & Memur & 3.60 & 1.28 & 2 \\
\hline & & İşçi & 4.17 & 1.14 & 1 \\
\hline & & Toplam & 4.09 & 1.18 & 1 \\
\hline \multirow{3}{*}{13} & \multirow{3}{*}{ Kendime olan saygımı kaybetme } & Memur & 3.68 & 1.09 & 1 \\
\hline & & İşçi & 3.86 & 1.32 & 3 \\
\hline & & Toplam & 3.84 & 1.28 & 3 \\
\hline \multirow{3}{*}{15} & \multirow{3}{*}{ Küçük düşme ve utanç duyma } & Memur & 3.47 & 1.24 & 3 \\
\hline & & İşçi & 4.16 & 1.16 & 2 \\
\hline & & Toplam & 4.05 & 1.19 & 2 \\
\hline
\end{tabular}


Süleyman Demirel Üniversitesi Vizyoner Dergisi, Yıl: 2021, Cilt: 12, Sayı: 31, 752-765.

Süleyman Demirel University Visionary Journal, Year: 2021, Volume: 12, No: 31, 752-765.

\begin{tabular}{|c|c|c|c|c|c|}
\hline Md. No. & İfadeler & Görev & $\overline{\mathrm{X}}$ & ss & Önem Sırası \\
\hline \multirow{3}{*}{9} & \multirow{3}{*}{ Kendimi kanıtlama gereksinimi } & Memur & 2.94 & 1.03 & 4 \\
\hline & & İşçi & 2.77 & 1.38 & 5 \\
\hline & & Toplam & 2.80 & 1.33 & 5 \\
\hline \multirow{3}{*}{5} & \multirow{3}{*}{ Daha sık olumsuz eleştiri ile karşılaşma } & Memur & 2.76 & 1.12 & 5 \\
\hline & & İşçi & 3.49 & 1.38 & 4 \\
\hline & & Toplam & 3.38 & 1.37 & 4 \\
\hline \multirow{3}{*}{$\mathrm{n}=254$} & \multirow{3}{*}{ Toplam } & Memur & 3.29 & 0.77 & \\
\hline & & İşçi & 3.69 & 0.90 & \\
\hline & & Toplam & 3.36 & 0.89 & \\
\hline
\end{tabular}

Tablo 2 incelendiğinde memurların en çok katıldıkları ifadenin " Kendime olan saygımı kaybetme” iken işçilerin en çok katıldığı ifadenin ise "yaptığım hataların göze batması" olduğu görülmektedir. Aşağıda tablo 3 'te iş ve özel yaşam dengesi hakkında endişeler alt boyutuna ilişkin aritmetik ortalama, standart sapma ve göreli önem sıra değerleri sunulmuştur.

Tablo 3. İş ve Özel Yaşam Dengesi Hakkında Endişeler Alt Boyutuna İlişkin Aritmetik Ortalama, Standart Sapma ve Göreli Önem Sıra Değerleri

\begin{tabular}{|c|c|c|c|c|c|}
\hline Md. No. & İfadeler & Görev & $\bar{X}$ & ss & Önem Sırası \\
\hline \multirow{3}{*}{2} & \multirow{3}{*}{ Aileme ihmal etme ihtimali } & Memur & 3.81 & 0.86 & 2 \\
\hline & & İşçi & 3.82 & 1.19 & 3 \\
\hline & & Toplam & 3.82 & 1.15 & 3 \\
\hline \multirow{3}{*}{14} & \multirow{3}{*}{ Ailevi yükümlülükleri yerine getirememe } & Memur & 3.97 & 1.02 & 1 \\
\hline & & İşçi & 4.31 & 1.06 & 1 \\
\hline & & Toplam & 4.26 & 1.06 & 1 \\
\hline \multirow{3}{*}{16} & \multirow{3}{*}{ Özel hayatın hiç kalmama riski } & Memur & 3.73 & 1.17 & 3 \\
\hline & & İşçi & 3.98 & 1.19 & 2 \\
\hline & & Toplam & 3.94 & 1.19 & 2 \\
\hline \multirow{3}{*}{6} & \multirow{3}{*}{ İş ve aile yaşamı arasındaki denge sağlayamama ihtimali } & Memur & 3.52 & 1.26 & 4 \\
\hline & & İşçi & 3.63 & 1.28 & 4 \\
\hline & & Toplam & 3.62 & 1.27 & 4 \\
\hline \multirow{3}{*}{4} & \multirow{3}{*}{ Uğraşlarıma zaman ayıramama } & Memur & 3.36 & 0.99 & 5 \\
\hline & & İşçi & 3.03 & 1.16 & 5 \\
\hline & & Toplam & 3.08 & 1.14 & 5 \\
\hline \multirow{3}{*}{8} & \multirow{3}{*}{ Arkadaş çevresine daha az vakit ayırma } & Memur & 3.15 & 1.05 & 6 \\
\hline & & İşçi & 2.93 & 1.15 & 6 \\
\hline & & Toplam & 2.97 & 1.14 & 6 \\
\hline \multirow{3}{*}{$n=254$} & \multirow{3}{*}{ Toplam } & Memur & 3.59 & 0.75 & \\
\hline & & İşçi & 3.62 & 0.88 & \\
\hline & & Toplam & 3.61 & 0.86 & \\
\hline
\end{tabular}

Tablo 3 incelendiğinde memurların en çok katıldığı ifadenin "Ailevi yükümlülükleri yerine getirmeme” olurken, işçilerin en çok katıldığı ifadenin aynı şekilde "Ailevi yükümlülükleri yerine getirememe” olduğu görülmektedir. Aşağıda tablo 4'te kendine ve çevresine zarar verme endişesi alt boyutuna ilişkin aritmetik ortalama, standart sapma ve göreli önem sıra değerleri sunulmuştur. 
Süleyman Demirel Üniversitesi Vizyoner Dergisi, Yıl: 2021, Cilt: 12, Sayı: 31, 752-765.

Süleyman Demirel University Visionary Journal, Year: 2021, Volume: 12, No: 31, 752-765.

Tablo 4. Kendine ve Çevresine Zarar Verme Endişesi Alt boyutuna İlişkin Aritmetik Ortalama, Standart Sapma ve Göreli Önem Sıra Değerleri

\begin{tabular}{|c|c|c|c|c|c|}
\hline Md. No. & İfadeler & Görev & $\overline{\mathrm{X}}$ & SS & Önem Sırası \\
\hline \multirow{3}{*}{11} & \multirow{3}{*}{ Aşırı kuralcı ve sert bir insana dönüşme } & Memur & 3.78 & 1.14 & 2 \\
\hline & & İşçi & 4.01 & 1.21 & 2 \\
\hline & & Toplam & 3.97 & 1.20 & 2 \\
\hline \multirow{3}{*}{10} & \multirow{3}{*}{ Eş veya arkadaşıyla sorun yaşama olasıllı̆ 1} & Memur & 3.34 & 1.23 & 5 \\
\hline & & İşçi & 3.64 & 1.34 & 5 \\
\hline & & Toplam & 3.60 & 1.32 & 5 \\
\hline \multirow{3}{*}{12} & \multirow{3}{*}{ Sağlık sorunlarının ortaya çıkması } & Memur & 3.78 & 1.21 & 3 \\
\hline & & İşçi & 3.71 & 1.26 & 4 \\
\hline & & Toplam & 3.72 & 1.25 & 4 \\
\hline \multirow{3}{*}{7} & \multirow{3}{*}{ Verdiğim kararların çalışanları incitmesi } & Memur & 3.71 & 1.20 & 4 \\
\hline & & İşçi & 3.81 & 1.21 & 3 \\
\hline & & Toplam & 3.79 & 1.20 & 3 \\
\hline \multirow{3}{*}{3} & \multirow{3}{*}{ Emrinde çalışanlara adaletsiz davranma } & Memur & 4.52 & 1.03 & 1 \\
\hline & & İşçi & 4.66 & 0.84 & 1 \\
\hline & & Toplam & 4.64 & 0.87 & 1 \\
\hline \multirow{3}{*}{$\mathrm{n}=254$} & \multirow{3}{*}{ Toplam } & Memur & 3.83 & 0.91 & \\
\hline & & İşçi & 3.96 & 0.89 & \\
\hline & & Toplam & 3.94 & 0.89 & \\
\hline
\end{tabular}

Tablo 4 incelendiğinde memurların en çok katıldığı ifade "Emrinde çalışanlara adaletsiz davranma" olurken, işçilerin en çok ifadenin aynı şekilde "Emrinde çalışanlara adaletsiz davranma" olduğu görülmektedir. Aşağıda tablo 5 'te istihdam türüne göre bağımsız gruplar t-testi sonuçları sunulmuştur.

Tablo 5. İstihdam Türüne Göre Bağımsız Gruplar T-Testi Sonuçları

\begin{tabular}{|c|c|c|c|c|c|c|c|}
\hline Alt Boyut & İstihdam Türü & $\mathbf{n}$ & $\bar{X}$ & ss & sd & $\mathbf{t}$ & $\mathbf{p}$ \\
\hline \multirow{2}{*}{$\begin{array}{l}\text { Başarısız Olma } \\
\text { Endişesi }\end{array}$} & Memur & 38 & 3.29 & .77 & \multirow{2}{*}{243} & \multirow{2}{*}{2.57} & \multirow{2}{*}{.01} \\
\hline & İşçi & 207 & 3.69 & .90 & & & \\
\hline \multirow{2}{*}{$\begin{array}{l}\text { İş ve Özel } \\
\text { Yaşam Dengesi }\end{array}$} & Memur & 38 & 3.59 & .75 & \multirow{2}{*}{243} & \multirow{2}{*}{.18} & \multirow{2}{*}{.857} \\
\hline & İşçi & 207 & 3.62 & .88 & & & \\
\hline \multirow{2}{*}{$\begin{array}{l}\text { K. ve Ç. Zarar } \\
\text { Verme }\end{array}$} & Memur & 38 & 3.83 & .91 & \multirow{2}{*}{243} & \multirow{2}{*}{.87} & \multirow{2}{*}{.386} \\
\hline & İşçi & 207 & 3.96 & .89 & & & \\
\hline
\end{tabular}

Tablo 5 incelendiğinde başarısız olma endişesi alt boyutunda istihdam türüne göre anlamlı bir farklılık bulunduğu görülmektedir $(\mathrm{p}<0.05)$. İşçilerin başarısız olma endişeleri memurlara nazaran daha yüksektir. Öte yandan iş ve özel yaşam dengesi hakkında endişeler ile kendine ve çevresine zarar verme endişesi boyutlarında anlamlı bir farklılık bulunmamaktadır. Aşağıda tablo 6'da cinsiyete göre bağımsız gruplar t-testi sonuçları sunulmuştur. 
Süleyman Demirel Üniversitesi Vizyoner Dergisi, Yıl: 2021, Cilt: 12, Sayı: 31, 752-765.

Süleyman Demirel University Visionary Journal, Year: 2021, Volume: 12, No: 31, 752-765.

Tablo 6. Cinsiyete Göre Bağımsız Gruplar T-Testi Sonuçları

\begin{tabular}{|c|c|c|c|c|c|c|c|}
\hline Alt Boyut & Cinsiyet & $\mathbf{n}$ & $\bar{X}$ & SS & sd & $\mathbf{t}$ & $\mathbf{p}$ \\
\hline \multirow{2}{*}{$\begin{array}{l}\text { Başarısız Olma } \\
\text { Endişesi }\end{array}$} & Kadın & 65 & 3.78 & .88 & \multirow{2}{*}{243} & \multirow{2}{*}{1.60} & \multirow{2}{*}{.11} \\
\hline & Erkek & 180 & 3.58 & .89 & & & \\
\hline \multirow{2}{*}{$\begin{array}{l}\text { İş ve Özel } \\
\text { Yaşam Dengesi }\end{array}$} & Kadın & 65 & 3.75 & .75 & \multirow{2}{*}{243} & \multirow{2}{*}{1.43} & \multirow{2}{*}{.15} \\
\hline & Erkek & 180 & 3.57 & .90 & & & \\
\hline \multirow{2}{*}{$\begin{array}{l}\text { K. ve Ç. Zarar } \\
\text { Verme }\end{array}$} & Kadın & 65 & 4.13 & .79 & \multirow{2}{*}{243} & \multirow{2}{*}{1.98} & \multirow{2}{*}{.049} \\
\hline & Erkek & 180 & 3.88 & .92 & & & \\
\hline
\end{tabular}

Tablo 6 incelendiğinde, kendine ve çevresine zarar verme alt boyutunda cinsiyete göre anlamlı bir farklılık bulunduğu görülmektedir $(\mathrm{p}<0.05)$. Kadın çalışanların kendine ve çevrelerine zarar verme endişelerinin erkek çalışanlara nazaran daha yüksektir. Başarısız olma endişesi ile iş ve özel yaşam dengesi hakkında endişeler alt boyutlarında cinsiyete göre anlamlı bir fark bulunmamaktadır. Aşağıda tablo 7'de medeni duruma bağımsız gruplar t-testi sonuçları sunulmuştur.

Tablo 7. Medeni Duruma Göre Bağımsız Gruplar T-Testi Sonuçları

\begin{tabular}{|c|c|c|c|c|c|c|c|}
\hline Alt Boyut & Medeni Durum & $\mathbf{n}$ & $\bar{X}$ & ss & sd & $\mathbf{t}$ & $\mathbf{p}$ \\
\hline \multirow{2}{*}{$\begin{array}{l}\text { Başarısız Olma } \\
\text { Endişesi }\end{array}$} & Evli & 189 & 3.64 & .88 & \multirow{2}{*}{243} & \multirow{2}{*}{.16} & \multirow{2}{*}{.870} \\
\hline & Bekâr & 56 & 3.61 & .95 & & & \\
\hline \multirow{2}{*}{$\begin{array}{l}\text { İş ve Özel } \\
\text { Yaşam Dengesi }\end{array}$} & Evli & 189 & 3.63 & .86 & \multirow{2}{*}{243} & \multirow{2}{*}{.42} & \multirow{2}{*}{.674} \\
\hline & Bekâr & 56 & 3.57 & .87 & & & \\
\hline \multirow{2}{*}{$\begin{array}{l}\text { K. ve Ç. Zarar } \\
\text { Verme }\end{array}$} & Evli & 189 & 3.95 & .92 & \multirow{2}{*}{243} & \multirow{2}{*}{.08} & \multirow{2}{*}{.936} \\
\hline & Bekâr & 56 & 3.93 & .81 & & & \\
\hline
\end{tabular}

Tablo 7 incelendiğinde, başarısız olma endişesi, iş ve özel yaşam dengesi hakkında endişesi ile kendine ve çevresine zarar verme endişesi alt boyutlarında medeni duruma göre anlamlı bir farklılık bulunmadığ görülmektedir $(\mathrm{p}<0.05)$. Aşağıda tablo 8'de mesleki kıdeme göre Kruskal Wallis-H testi sonuçları sunulmuştur.

Tablo 8. Mesleki Kıdeme Göre Kruskal Wallis-H Testi Sonuçları

\begin{tabular}{|c|c|c|c|c|c|c|c|c|}
\hline Alt Boyutlar & Mesleki Kıdem & $\mathbf{n}$ & $\bar{X}$ & Sira Ort. & $X^{2}$ & sd & $\mathbf{p}$ & Anlamlı Fark \\
\hline \multirow{3}{*}{$\begin{array}{l}\text { Başarısız Olma } \\
\text { Endişesi }\end{array}$} & $0-10$ yıl & 167 & 3.64 & 124.78 & \multirow{3}{*}{1.185} & \multirow{3}{*}{2} & \multirow{3}{*}{.553} & \multirow{3}{*}{---} \\
\hline & $11-20 \mathrm{y} 1 \mathrm{l}$ & 64 & 3.57 & 115.74 & & & & \\
\hline & 21 ve üzeri & 14 & 3.78 & 135.00 & & & & \\
\hline \multirow{3}{*}{$\begin{array}{l}\text { İş ve Özel } \\
\text { Yaşam Dengesi }\end{array}$} & $0-10$ y1l & 167 & 3.61 & 122.87 & \multirow{3}{*}{.033} & \multirow{3}{*}{2} & \multirow{3}{*}{.984} & \multirow{3}{*}{---} \\
\hline & $11-20 \mathrm{y} 11$ & 64 & 3.64 & 123.95 & & & & \\
\hline & 21 ve üzeri & 14 & 3.59 & 120.29 & & & & \\
\hline \multirow{3}{*}{$\begin{array}{l}\text { K. ve Ç. Zarar } \\
\text { Verme }\end{array}$} & $0-10 \mathrm{y} 11$ & 167 & 3.94 & 123.36 & \multirow{3}{*}{.678} & \multirow{3}{*}{2} & \multirow{3}{*}{.712} & \multirow{3}{*}{---} \\
\hline & $11-20$ y1l & 64 & 3.95 & 119.18 & & & & \\
\hline & 21 ve üzeri & 14 & 3.92 & 136.14 & & & & \\
\hline
\end{tabular}

Tablo 8'deki sonuçlar incelendiğinde, katılımcıların başarısız olma endişesi, iş ve özel yaşam dengesi hakkında endişesi ile kendine ve çevresine zarar verme endişesi alt boyutlarına ilişkin algılarının mesleki kıdeme göre

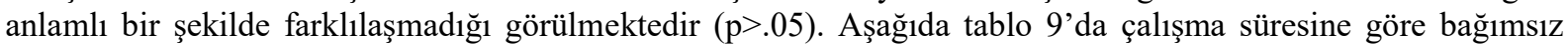
gruplar t-testi sonuçları sunulmuştur. 
Süleyman Demirel Üniversitesi Vizyoner Dergisi, Yıl: 2021, Cilt: 12, Sayı: 31, 752-765.

Süleyman Demirel University Visionary Journal, Year: 2021, Volume: 12, No: 31, 752-765.

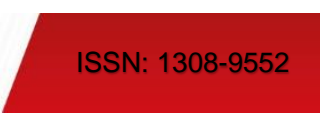

Tablo 9. Eğitim Durumuna Göre Bağımsız Gruplar T-Testi Sonuçları

\begin{tabular}{|c|c|c|c|c|c|c|c|}
\hline Alt Boyut & Eğitim Durumu & $\mathbf{n}$ & $\bar{X}$ & SS & sd & $\mathbf{t}$ & $\mathbf{p}$ \\
\hline \multirow{2}{*}{$\begin{array}{l}\text { Başarısız Olma } \\
\text { Endişesi }\end{array}$} & Lise ve altı & 154 & 3.72 & .91 & \multirow{2}{*}{243} & \multirow{2}{*}{2.04} & \multirow{2}{*}{.042} \\
\hline & Önlisans ve üstü & 91 & 3.48 & .85 & & & \\
\hline \multirow{2}{*}{$\begin{array}{l}\text { İş ve Özel } \\
\text { Yaşam Dengesi }\end{array}$} & Lise ve alt & 154 & 3.69 & .87 & \multirow{2}{*}{243} & \multirow{2}{*}{1.69} & \multirow{2}{*}{.092} \\
\hline & Önlisans ve üstü & 91 & 3.49 & .83 & & & \\
\hline \multirow{2}{*}{$\begin{array}{l}\text { K. ve Ç. Zarar } \\
\text { Verme }\end{array}$} & Lise ve alt 1 & 154 & 4.00 & .92 & \multirow{2}{*}{243} & \multirow{2}{*}{1.18} & \multirow{2}{*}{.296} \\
\hline & Önlisans ve üstü & 91 & 3.85 & .85 & & & \\
\hline
\end{tabular}

Tablo 9 incelendiğinde, başarısız olma endişesi alt boyutunda lise ve altı düzeyde eğitime sahip katılımcılarla önlisans ve üstü düzeyde eğitime sahip katılımcıların görüşleri arasında anlamlı bir farklılık bulunduğu görülmektedir $(\mathrm{p}<0.05)$. Lise ve altı düzeye sahip katılımcıların başarısız olma endişeleri daha yüksek bulunmuştur. Öte yandan, iş ve özel yaşam dengesi hakkında endişeler ile kendine ve çevresine zarar verme endişesi alt boyutlarında eğitim durumuna göre anlamlı bir farklılık bulunmadığı görülmektedir. Aşağıda tablo 10 ’da yöneticilik deneyimine göre bağımsız gruplar t-testi sonuçları sunulmuştur.

Tablo 10. Yöneticilik Deneyimine Göre Bağımsız Gruplar T-Testi Sonuçları

\begin{tabular}{|c|c|c|c|c|c|c|c|}
\hline Alt Boyut & Yöneticilik Deneyimi & $\mathbf{n}$ & $\bar{X}$ & ss & sd & $\mathbf{t}$ & $\mathbf{p}$ \\
\hline \multirow{2}{*}{$\begin{array}{l}\text { Başarısız Olma } \\
\text { Endişesi }\end{array}$} & Evet & 49 & 3.33 & .90 & \multirow{2}{*}{243} & \multirow{2}{*}{2.68} & \multirow{2}{*}{.008} \\
\hline & Hayır & 196 & 3.71 & .88 & & & \\
\hline \multirow{2}{*}{$\begin{array}{l}\text { İş ve Özel } \\
\text { Yaşam Dengesi }\end{array}$} & Evet & 49 & 3.40 & .98 & \multirow{2}{*}{243} & \multirow{2}{*}{1.92} & \multirow{2}{*}{.056} \\
\hline & Hayır & 196 & 3.67 & .82 & & & \\
\hline \multirow{2}{*}{$\begin{array}{l}\text { K. ve Ç. Zarar } \\
\text { Verme }\end{array}$} & Evet & 49 & 3.67 & .98 & \multirow{2}{*}{243} & \multirow{2}{*}{2.38} & \multirow{2}{*}{.018} \\
\hline & Hayır & 196 & 4.01 & .86 & & & \\
\hline
\end{tabular}

Tablo 10 incelendiğinde, başarısız olma endişesi ile kendine ve çevresine zarar verme endişesi alt boyutlarında yöneticilik deneyimi olan ve olmayan katılımcıların görüşleri arasında anlamlı bir farklılık bulunduğu görülmektedir $(\mathrm{p}<0.05)$. Yöneticilik deneyimi olmayan katılımcılar, geçmişte yöneticilik yapan katılımcılara göre daha fazla başarısız olma ve daha fazla kendine ve çevresine zarar verme endişesi taşımaktadır. Öte yandan iş ve özel yaşam dengesine ilişkin endişeler alt boyutunda katılımcıların görüşleri arasında anlamlı bir farklılık bulunmamaktadır. Aşağıda tablo 11'de yönetici olma isteğine göre bağımsız gruplar t-testi sonuçları sunulmuştur.

Tablo 11. Yönetici Olma İsteğine Göre Bağımsız Gruplar T-Testi Sonuçları

\begin{tabular}{llcccccc}
\hline Alt Boyut & Yönetici Olma İsteği & $\mathbf{n}$ & $\bar{X}$ & ss & sd & t & p \\
\hline Başarısız Olma & Evet & 113 & 3.47 & .88 & \multirow{2}{*}{243} & 2.53 & .012 \\
Endişesi & Hayır & 132 & 3.76 & .89 & & & \multirow{2}{*}{013} \\
\hline İş ve Özel & Evet & 113 & 3.47 & .94 & \multirow{2}{*}{243} & 2.49 & .013 \\
Yaşam Dengesi & Hayır & 132 & 3.74 & .77 & & & \multirow{2}{*}{001} \\
\hline \multirow{2}{*}{ K. ve Ç. Zarar } & Evet & 113 & 3.74 & .97 & \multirow{2}{*}{243} & 3.30 & .001 \\
\hline
\end{tabular}

Tablo 11 incelendiğinde, başarısız olma endişesi, iş ve özel yaşam dengesi hakkında endişeler ile kendine ve çevresine zarar verme endişesi alt boyutlarında yönetici olma isteğine göre katılımcıların görüşleri arasında anlamlı bir farklılık bulunduğu görülmektedir $(\mathrm{p}<0.05)$. Yönetici olmak isteyen katılımcılar başarısız olma konusunda, iş ve özel yaşam dengesi hakkında ve kendilerine ve çevrelerine zarar verme konusunda daha az endişelenmektedir. 


\section{TARTIŞMA, SONUÇ VE ÖNERILER}

Elde edilen bulgular neticesinde Burdur Gençlik ve Spor İl Müdürlüğü çalışanlarının lider olma endişelerinin yüksek düzeyde olduğu görülmektedir. Bu konuda yapılan araştırmalar kamu çalışanlarının liderlik rollerini üstlenmedeki endişelerinin, bilgi ve özgüven eksikliği gibi bireysel etkenlerden etkilenebileceği gibi, kamu örgütlerinin iş çevrelerini kısıtlayan katı mevzuattan da etkilenebileceğini ifade etmişlerdir. (Anderson, Brien, McNamara, O’Hara ve McIsaac, 2011; Chan ve Drasgow, 2001; Şahin ve Gül, 2011: 246-247).

Memurların lider olma endişeleri işçilere göre başarısız olma alt boyutunda daha düşük seviyedir. Bu durum memurların 657 sayılı Devlet Memurları kanuna tabi olmaları nedeniyle işçilere nazaran görev alanlarının geniş olması, kurumsal yapı ve iş süreçlerine daha fazla hâkim olmalarından kaynaklanabilir. Diğer taraftan iş ve özel yaşam dengesi hakkında endişe ile kendisine ve çevresine zarar verme endişesi alt boyutlarında farklılık bulunmaması çalışma koşularının öngörülebilir mevzuatla düzenlenmesinden kaynaklanabilir. Başka bir ifadeyle, memurların 657 sayılı Devlet Memurları Kanununa ve İşçilerin ise 4857 sayılı İş Kanunu tabi olmaları çalışma koşullarını, kendilerine ve özel yaşamlarına ayırdıkları zamanın süresini ve çalışma arkadaşlarına karşı hassasiyetlerini şekillendirebilmektedir.

Kadınların erkeklere nazaran kendine ve çevresine zarar verme endişesi alt boyutunda daha yüksek düzeyde endişe yaşadıkları görülmektedir. Bu durum toplumun kadınlara verdiği rollerden kaynaklanabilir. Kadınlar erkeklere göre daha hassas, şefkatli, korumacı ve anne rollerine sahiptirler. Bu nedenle kendine ve çevresindekilere zarar vermeme konusunda daha çok hassasiyet göstermeleri muhtemeldir (Günay ve Bener, 2011: 167; Pekel, 2019 : 31 33). Başarısız olma endişesi alt boyutunda cinsiyet rollerinin etkiye sahip olmadığı görülmektedir. Aynı doğrultuda Çekiç (2016: 87) çalışanların lider olma endişelerin cinsiyet faktöründen etkilenmediği sonucuna ulaşmıştır. İş ve özel yaşam dengesi hakkındaki endişelerde cinsiyete göre farklılık bulunmaması, kadın ve erkek çalışanların çalışma saatlerinin ve tatil zamanlarının 657 sayılı Devlet Memurları Kanunu ve işçilerin ise 4857 sayılı İş Kanunu ile düzenlendiği için iş yaşamları ve aile yaşamlarına yeteri kadar vakit ayırma imkânı bulmaları ile açıklanabilir.

Çalışanların medeni durumlarının lider olma endișesi düzeyini etkilemediği görülmektedir. Aynı doğrultuda Hoşgör vd. (2016: 357) lider olma endişesi ile medeni durum arasında ilişki olmadığı sonucuna ulaşmıştır. Bu durum kamu sektöründeki 657 sayılı Devlet Memurları Kanunu ve 4857 sayılı İş Kanunu gibi yasal mevzuatın etkisiyle açıklanabilir. Çünkü ilgili mevzuat çalışanların ailelerine ve çevrelerine ayırdıkları zamandan feragat etmeden başarılı olmalarına şans tanımaktadır. Ayrıca iş ve özel yaşam dengesi hakkında endişesi ile kendine ve çevresine zarar verme endişesi alt boyutlarında farklılık olmaması ilgili mevzuatın tüm çalışanların özel yaşamını güvence altına alarak, yeteri kadar ailelerine ve çevresine vakit ayırmasına imkân tanıması ve işyerindeki çalışanlar arasındaki ilişkilerin yine aynı mevzuatla düzenlemesi ile ilişkilendirilebilir.

Çalışanların başarısız olma endişesi, iş ve özel yaşam dengesi hakkında endişesi ile kendine ve çevresine zarar verme endişesi alt boyutları mesleki kıdemden etkilenmediği görülmektedir. Aynı doğrultuda Demircioglu ve Chowdhury (2020: 8) mesleki kıdemin lider olma yönelimi üzerinde herhangi bir etkiye sahip olmadığını belirtmişlerdir. Başka bir ifadeyle kamu kurumlarında kıdem, çalışanların liderlikle ilgili kararları üzerinde etkili değildir. Yine Jacobsen ve Andersen (2017: 266-267) mesleki kıdemin kamu çalışanlarının öz yeterliliklerinin anlamlı yordayıcısı olmadığını, farklı kıdemlere sahip çalışanların aynı çalışma koşullarına tabi olmalarının, öngörülebilir bir kurumsal çevre oluşturarak çalışma süresi ne olursa olsun kamu çalışanlarının liderlik konusunda benzer tutumlara yol açtı̆̆ını ifade etmişlerdir.

Eğitim seviyesine göre lise ve altı eğitim seviyesine sahip olan çalışanların başarısız olma endişelerinin yüksek düzeyde çıktığı ve önlisans ve üstü eğitim seviyesine sahip olanların düşük düzeyde çıktığı görülmektedir. Aynı doğrultuda Elmuti, Minnis ve Abebe (2005: 1026) eğitimle birlikte çalışanların becerilerinin geliştiği, özgüvenlerin artığı ve başarısızlık korkularının azaldığını belirtmişlerdir. Başka bir ifadeyle mevzuat gibi kurumsal baskı öğelerinin yoğun bir şekilde hissedildiği çevrelerde faaliyet gösteren kamu çalışanlarının eğitim düzeyleri yükseldikçe bu kurumsal çevreye ilişkin farkındalıkları yükselebilir ve kurumsal çevrenin taleplerine nasıl yanıt verecekleri konusunda bilgi birikimi oluşturabileceği ifade edilmiştir. İş ve özel yaşam dengesi hakkında endişesi ile kendine ve çevresine zarar verme endişesi alt boyutlarında eğitim durumuna göre anlamlı bir farklılık bulunmaması çalışma hayatını düzleyen ilgili mevzuatın tüm çalışanlara aynı hak ve sorumlulukları vermesinden kaynaklanabilir.

Daha önce yöneticilik deneyimi olmayan çalışanların başarısız olma endişesi ve kendisine ve çevresine zarar verme endişesi alt boyutlarında endişe düzeylerin yüksek düzeyde olduğu görülmektedir. Benzer şekilde Araç 
Ilgar'a göre (2019: 70-75) daha yöneticilik deneyimi olan kamu çalışanlarının iş süreçlerini daha önce tecrübe ettikleri için kendilerine yeteri kadar güven duymaktalar ve bu durum endişe düzeylerini düşürmektedir. Çalışanlar arasında iş ve özel yaşam dengesi kuramama endişesi alt boyutunda farklılık olmaması ise iş ve özel yaşamı düzenleyen ilgili mevzuatın tüm çalışanlara eşit haklar sağlamasından kaynaklanabilir.

Çalışanların yönetici olma isteği durumuna göre lider olma endişesi alt boyutlarından başarısız olma endişesi, iş ve özel yaşam dengesi hakkında endişeler ile kendine ve çevresine zarar verme endişelerinin düşük düzeyde çıktığ görülmektedir. Bu durum yöneticilik yapma isteği olan çalışanların lider olmanın kendisine sağlayacağı imkân ve olanakları arzu etmeleri ile açıklanabilir (Araç Ilgar, 2019: 74-75).

Sonuç olarak Burdur Gençlik ve Spor İl Müdürlüğü çalışanlarının lider olma endişelerinin istihdam türü, cinsiyet, eğitim seviyesi, yöneticilik deneyimi ve yönetici olma istekleri gibi faktörlerden etkilendiği görülmektedir. Bununla birlikte lider olma süreci ilgili belirsizlik, bilgi eksikliği, yetersizlik hissi çalışanların lider olma endişelerini daha da artırmaktadır. Bu veriler neticesinde çalışanların lider olma endişelerini en aza indirgemek için aşağıdaki önerilerde bulunulabilir.

- Öncelikli olarak çalışanları liderliğe hazırlayıcı temel eğitimler verilebilir. Bu eğitim kapsamında:

- Liderliğin getirdiği sorumluluklar konusunda çalışanlar bilgilendirilebilir.

- Liderliğin çalışanlara yüklediği maliyetler konusunda bilgilendirmeler yapılabilir.

- Liderliğin sağlayacağı olası avantajlar anlatılabilir.

- Kriz ve stres yönetimi eğitimleri verilebilir.

- Ayrıca çalışanların özellikle işçilerin yönetime katılımları sağlanarak bilgi, tecrübe ve özgüvenlerinin artırılmasına katkıda bulunulabilir.

Bu araştırma küçük ölçekteki kamu kurumu ile sınırlıdır. Daha büyük ölçekteki kamu kurum ve kurum kuruluşları ile geniş çaplı araştırmalar yapılarak farklı sonuçlara ve genellemelere ulaşılabilir. Ayrıca kamu sektörlerinde kurumsal çevrenin lider olma endişesi etkileri üzerine çalışmalar yapılabilir.

\section{YAZARIN BEYANI}

Katkı Oranı Beyanı: Yazar, çalışmanın tümüne tek başına katkı sağlamıştır.

Destek ve Teşekkür Beyanı: Çalışmada herhangi bir kurum ya da kuruluştan destek alınmamıştır.

Çatışma Beyanı: Çalışmada herhangi bir potansiyel çıkar çatışması söz konusu değildir.

\section{KAYNAKÇA}

Akbaş, G. ve Korkmaz, L. (2017). Kadın yöneticiler: Görünmez engellerin gölgesinde yükselme çabası. Işs ve İnsan Dergisi, 4(2), 73-86.

Anderson, K., Brien, K., McNamara, G., O’Hara, J. ve McIsaac, D. (2011). Reluctant leaders: Why are some capable leaders not interested in the principalship?. International Journal of Management in Education, 5(4), 384-400.

Anderson, K., Brien, K., McNamara, G., O’Hara, J. ve McIsaac, D. (2011). Reluctant leaders: Why are some capable leaders not interested in the principalship?. International Journal of Management in Education, 5(4), 384-400.

Araç Ilgar, E. (2019). Beden eğitimi öğretmenlerinin yönetici olmaya isteklilik düzeylerinin belirlenmesi. Spormetre Beden Eğitimi ve Spor Bilimleri Dergisi, 17(1), 63-77.

Aycan, Z. ve Shelia, S. (2019). "Leadership? No, thanks!” A new construct: worries about leadership. European Management Review, 16(1), 21-35.

Baloğlu, N. (2011). Dağıtımcı liderlik: Okullarda dikkate alınması gereken bir liderlik yaklaşımı. Journal of Kirsehir Education Faculty, 12(3). 127-148. 
Binen, B. (2013). Kadın ögretmenlerin yönetici olma taleplerini etkileyen etkenler: Adana ili araştırmast. Master's Thesis, Çă̆ Üniversitesi Sosyal Bilimler Enstitüsü, Mersin.

Brue, K. L. (2018). Harmony and help: Recognizing the impact of work-life balance for women leaders. Journal of Leadership Education, 17(4), 214-243.

Chan, K. Y. ve Drasgow, F. (2001). Toward a theory of individual differences and leadership: understanding the motivation to lead. Journal of Applied Psychology, 86(3), 481-498.

Çekiç, B. (2016). Bahçelievlerde meslek lisesi öğretmenlerinin idareciliğe bakış açıları ve idareciliği tercih nedenleri, Doktora Tezi, İstanbul Aydın Üniversitesi Sosyal Bilimler Enstitüsü, İstanbul.

Çelik, V. (1997). Eğitim yönetiminde vizyoner liderlik. Kuram ve Uygulamada Egitim Yönetimi Dergisi, 3(4), 465-474.

Demircioglu, M. A. ve Chowdhury, F. (2020). Entrepreneurship in public organizations: the role of leadership behavior. Small Business Economics, 1-17.

Dönmez, C. ve Uslu, S. (2013). Sosyal bilgiler öğretmen adaylarının öğretmenlik mesleğine yönelik tutumları. Türk Eğitim Bilimleri Dergisi, 11(1), 42-63.

Elmuti, D., Minnis, W. ve Abebe, M. (2005). Does education have a role in developing leadership skills?. Management Decision. 1018-1031.

Epitropaki, O. (2018). Self-selection bias in leadership. R. E. Riggio (Ed.), What's wrong with leadership?: Improving leadership research and practice içinde (89-104). New York, NY: Routledge.

Eraslan, L. (2004). Liderlikte post-modern bir paradigma: Dönüşümcü liderlik. Journal of Human Sciences, 1(1). $1-32$.

Garson, G. D. (2012). Testing Statistical Assumptions. Asheboro, Nc: Statistical Associates Publishing.

Giessner, S. R. ve Van Knippenberg, D. (2008). "License to fail”: Goal definition, leader group prototypicality, and perceptions of leadership effectiveness after leader failure. Organizational behavior and human decision processes, 105(1), 14-35.

Günay, G. ve Bener, Ö. (2011). Kadınların toplumsal cinsiyet rolleri çerçevesinde aile içi yaşamı algılama biçimleri. Türkiye Sosyal Araştırmalar Dergisi, 153(153). 157-171.

Günay, G. ve Özbilen, F. M. (2018). Öğretmenlerin okul yöneticiliği istekliliğini etkileyen faktörlerin belirlenmesi. Electronic Turkish Studies, 13(19). 1331-1344.

Hoşgör, H., Hoşgör, D. G., ve Memiş, K. (2016). Sosyo-demografik özellikler ile cam tavan sendromu arasındaki ilişki ve farklılıkların incelenmesi: Sağlık çalışanları örneği. Mustafa Kemal Üniversitesi Sosyal Bilimler Enstitüsü Dergisi, 13(35). 345-362.

Jacobsen, C. B. ve Bøgh Andersen, L. (2017). Leading public service organizations: How to obtain high employee self-efficacy and organizational performance. Public Management Review, 19(2), 253-273.

Mizrahi, R. ve Aracı, H. (2010). Kadın yöneticiler ve cam tavan sendromu üzerine bir araştırma. Organizasyon ve Yönetim Bilimleri Dergisi, 2(1), 149-156.

Pekel, E. (2019). Toplumsal cinsiyet rolleri ve kadının çalışma hayatındaki konumu. Balkan ve Yakın Doğu Sosyal Bilimler Dergisi, 5, 30-39.

Rigby, J. G. (2014). Three logics of instructional leadership. Educational Administration Quarterly, 50(4), 610644.

Soysal, A. ve Baynal, T. (2016). Sağlık kurumlarında cam tavan sendromu: Kayseri özel sağlık kurumlarında bir araştırma. Kahramanmaraş Sütçü Imam Üniversitesi Sosyal Bilimler Dergisi, 13(2). 225-264.

Spillane, J. P., Hallett, T. ve Diamond, J. B. (2003). Forms of capital and the construction of leadership: Instructional leadership in urban elementary schools. Sociology of Education, 76(1), 1-17 
Şahin, A., Taşpınar, Y., Eryeşil, K., ve Örselli, E. (2016). Kamu yönetiminde liderlik: Yönetici ve çalışanların liderlik algısı. Selçuk Üniversitesi Sosyal Bilimler Meslek Yüksek Okulu Dergisi, 18(2), 73-96.

Şahin, K. ve Gül, H. (2011). Bilgi toplumunda yeni bir liderlik yaklaşımı olarak transformasyonel liderlik ve kamu çalışanlarının transformasyonel liderlik algısı. Selçuk Üniversitesi Sosyal Bilimler Enstitüsü Dergisi, (25) 237-249.

Tahaoğlu, F. ve Gedikoğlu, T. (2009). İlköğretim okulu müdürlerinin liderlik rolleri. Kuram ve Uygulamada Ĕ̌itim Yönetimi Dergisi, 15(2), 274-298.

Tunçer, P. (2011). Örgütsel değişim ve liderlik. Sayıştay Dergisi, 80(1), 57-83.

Yeşil, A. (2016). Liderlik ve motivasyon teorilerine yönelik kavramsal bir inceleme. Uluslararası Akademik Yönetim Bilimleri Dergisi, 2 (3), 158-180. 